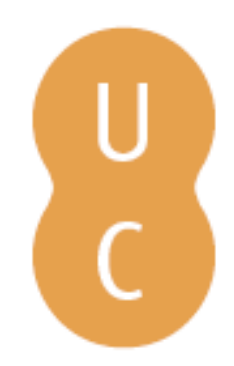

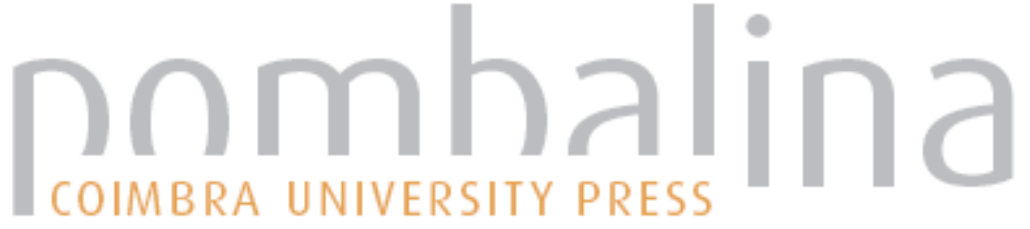

\section{The physiological demands of soccer: implications for youth trainning}

\author{
Autor(es): Reilly, Thomas
}

Publicado por: Imprensa da Universidade de Coimbra

URL

persistente: URI:http://hdl.handle.net/10316.2/32624

DOI: $\quad$ DOI:http://dx.doi.org/10.14195/978-989-26-0412-1_11

Accessed : $\quad$ 26-Apr-2023 07:01:38

A navegação consulta e descarregamento dos títulos inseridos nas Bibliotecas Digitais UC Digitalis, UC Pombalina e UC Impactum, pressupõem a aceitação plena e sem reservas dos Termos e Condições de Uso destas Bibliotecas Digitais, disponíveis em https://digitalis.uc.pt/pt-pt/termos.

Conforme exposto nos referidos Termos e Condições de Uso, o descarregamento de títulos de acesso restrito requer uma licença válida de autorização devendo o utilizador aceder ao(s) documento(s) a partir de um endereço de IP da instituição detentora da supramencionada licença.

Ao utilizador é apenas permitido o descarregamento para uso pessoal, pelo que o emprego do(s) título(s) descarregado(s) para outro fim, designadamente comercial, carece de autorização do respetivo autor ou editor da obra.

Na medida em que todas as obras da UC Digitalis se encontram protegidas pelo Código do Direito de Autor e Direitos Conexos e demais legislação aplicável, toda a cópia, parcial ou total, deste documento, nos casos em que é legalmente admitida, deverá conter ou fazer-se acompanhar por este aviso.

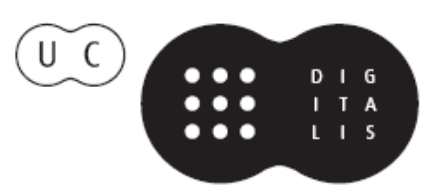


MANUEL COELHO E SILVA

ROBERT M. MALINA

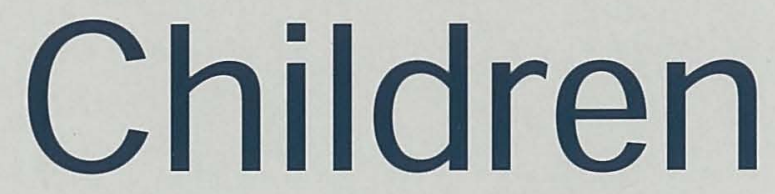

\section{and Youth}

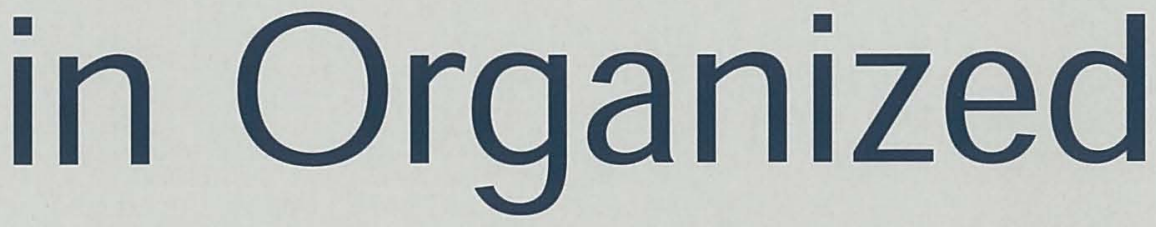

Sports 
(Página deixada propositadamente em branco) 
Manuel Coelho e Silva

Robert M. Malina

(Editors)

CHILDREN AND YOUTH IN ORGANIZED SPORTS

COIMBRA UNIVERSITY PRESS

2004 


$$
\begin{gathered}
\text { Editors } \\
\text { Manuel Coelho e Silva } \\
\text { and } \\
\text { Robert M. Malina } \\
\text { Publisher } \\
\text { Imprensa da Universidade de Coimbra } \\
\text { Coimbra University Press } \\
\text { Title } \\
\text { Children and Youth in Organized Sports }
\end{gathered}
$$

Date

March 2004

ISBN

972-8704-21-6

(Depósito legal n.: 208058/04)

Financial support

FCT Fundação para a Ciência e a 'Tecnologia MINISTÉRIO DA CIÊNCIA E DO ENSINO SUPERIOR Portugal

$$
\text { Apoio do Programa Operacional }
$$

Ciência, Tecnologia, Inovação do Quadro Comunitário de Apoio III

e

Câmara Municipal da Lousã

Faculdade de Ciências do Desporto e Educação Física

Universidade de Coimbra 


\section{THE PHYSIOLOGICAL DEMANDS OF SOCCER: IMPLICATIONS FOR YOUTH TRAINING}

\section{Thomas Reilly}

Research Institute for Sport and Exercise Sciences. Liverpool John Moores University

Henry Cotton Campus. 15-2I Webster Street .Liverpool. L3 2ET

UNITED KINGDOM

\section{INTRODUCTION: AN ERGONOMICS PERSPECTIVE}

A fundamental tenet of ergonomics is a focus on the human, whether male or female, young, adult or ageing. In the design of any activity, the tasks must be suited to the capability of the human. Such capabilities are limited, whether expressed in physical, physiological, psychological or perceptual motor terms. This notion of limited capacity is especially appropriate when youth soccer is concerned. The principle is that if the demands - of training or competitive match-play - exceed the individual's capacities, the result is excessive strain on that young person.

Sport does not necessarily comply with ergonomics principles since competition is associated with pushing back limits. Sports training theory relies on the principle of overload. The reasoning is that by imposing an overload on the organism, it gradually adapts to the training stress to reach a new level of performance capability. The athlete goes through a sequence of stages incorporating overload, recovery and adaptation in an upwardly spiralling cycle of improvement. Once the individual adapts to a new level of training stress, performance may attain a plateau so that the training stimulus must again be upgraded to induce further improvements.

This model of progressive overload becomes abstract when the individual fails to respond to training in the predicted way. Indeed performance may actually deteriorate even though the training stimulus is maintained. This phenomenon is known as 'overtraining' and sometimes referred to as 'overreaching'. Repeated scientific attempts to identify biological predictors of this state have proved inconclusive. In the context of the young soccer player, an 'overtrained' state would be highly undesirable. Negative consequences include absence from participation whilst reaching recovery, associated 'burnout' and a disaffection with playing the game.

The world of competitive sport differs from its occupational ergonomics counterpart in that the demands imposed during contests are unforgiving and 
cannot be adapted much by design intervention. Soccer is further complicated by the fact that success is determined by the sum of individual players' capabilities but by their harmonisation into an effective team unit. Nevertheless, individual profiles have implications for team selection and for interpreting fitness assessments, as is illustrated by Figure I.

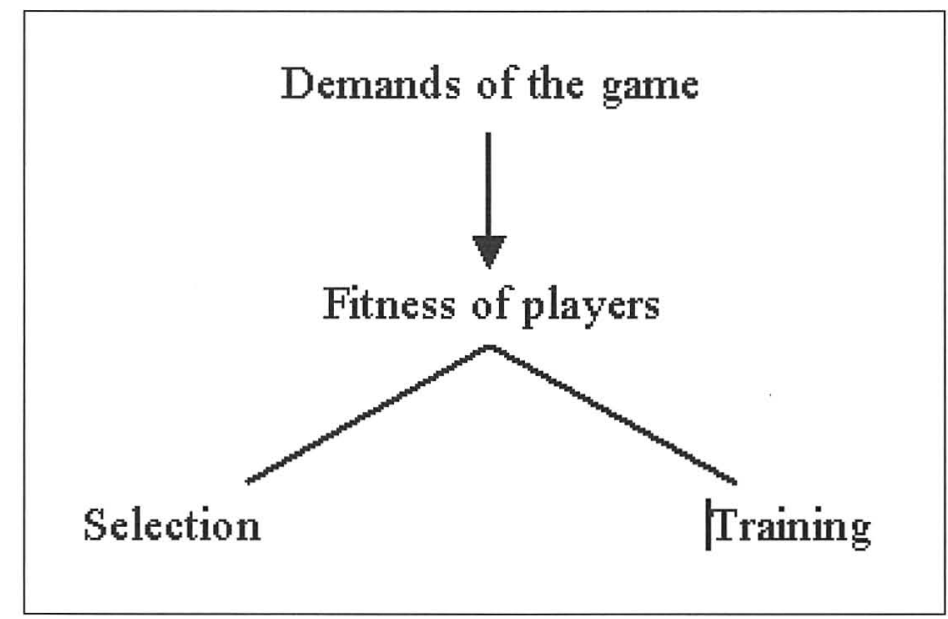

Figure I. An ergonomics approach to analysing match demands.

In recreational soccer, particularly among youth players, the activity levels and physiological responses to play may reflect the demands which individuals are prepared to impose on themselves. For this reason the best insights into the specific stresses of soccer are evident when the game is played at the highest tempo possible. Examining the game at elite professional level provides useful scientific information about the unique physiological demand inherent in playing it.

A quasi-ergonomics approach is followed in this chapter. First, the demands of competitive soccer are covered with a view towards later outlining their implications for youth soccer. Further insights are provided by considering the fitness levels reached by elite players and their training programmes in order to prepare them for coping with the rigours of competition. Parallel studies are identified in young players as a check on the validity of the inferences for young players. Finally, there are consequences also for talent development and the necessity to be able to tolerate training over the period of developmental years. 


\section{PHYSIOLOGICAL RESPONSES TO MATCH-PLAY IN PROFSSEIONAL PLAYERS}

The physiological demands of top-class soccer are quantified by measuring responses of players during match-play. More detailed invasive methods may be employed by halting play at pre-determined time-points or obtaining measurements at half-time and at the end of a game. The latter approach has been adopted when muscle biopsies have been obtained from players. Laboratory investigations have utilised intermittent exercise models that simulate the exercise intensity of competitive play and elicit physiological responses comparable to it (Drust et al., 2000).

The energy expenditure during elite soccer match-play has been estimated to be about $5700 \mathrm{~kJ}$. This figure assumes the individual is male, weighs $75 \mathrm{~kg}$ and has a maximal oxygen uptake ( $\dot{V} O 2 \max$ ) of $60 \mathrm{ml} \mathrm{kg}^{-1} \mathrm{~min}^{-1}$ (Reilly et al., 2000a). This rate of energy expenditure represents a proportional utilisation of just above $70 \% \dot{V} O 2 \max$.

The major metabolic pathway employed during soccer match-play is aerobic (Bangsbo, 1994). It is not surprising, therefore, that muscle glycogen depots are severely reduced at the end of a game. Whilst the active muscles are heavily reliant on carbohydrate stores in muscle and liver depots, fat is also mobilised during exercise as reflected in elevated concentrations of free fatty acids during the second half. It is likely also that there is some contribution from protein to metabolism but its magnitude is below $5 \%$ of the total energy expended (Wagenmakers et al., 1989). It seems that metabolic responses to soccer match-play are broadly analogous to those experienced during endurance exercise such as distance running. The predominance of aerobic metabolism would suit young players since the development of the anaerobic system lags behind the aerobic system during adolescence (Borms, 1986).

Although match-play is dependent on the capability for sustaining a high average aerobic loading, crucial aspects of the game call for anaerobic efforts. On average, players must sprint all-out every 90 s and produce high-intensity efforts every 30s. The relative contribution of anaerobic activity in youth matches may be less than in professional games because of the delayed development of anaerobic metabolic pathways in the former (Reilly and Stratton, 1995).

Nevertheless, anaerobic power is relevant to youth soccer. It is important in accelerating the body over short runs, in leaping to contest possession of the ball in the air and in executing tackles. Muscle strength is relevant to many aspects of the game, in challenging for possession, in kicking the ball and balancing the body. Flexibility in muscle groups of the lower limbs 
is important in reducing injury risk in adult players (Ekstrand, 1982) and is likely to be relevant also to youth soccer players.

The energy expenditure during match-play is dependent among other things on the total distance covered. Consequently the distance covered is a useful index of the work-rate or exercise intensity (Reilly, 1997). It has proved sensitive to the influence of styles of play on work-rate and the fall-off in performance towards the end of a full game due to fatigue. A consistent influence on work-rate is imposed by the positional role of the player. Midfield players display the highest overall work-rates whilst centre-backs rely on anaerobic efforts and unorthodox movements in backwards and sideways directions (Reilly, 1997). It may, therefore, be prudent for youth players not to specialise too early so they can gain experience of the activities associated with different positions on the field.

\section{PHYSIOLOGICAL CAPABILITIES OF ADULT PLAYERS}

Fitness profiles of top professional soccer players provide a testimony to the requirements for match-play. In view of the aerobic demands of the game, the oxygen transport system is deemed to be important for successful performance. Maximal aerobic power is reflected in the maximal oxygen uptake ( $\dot{V} O_{2} \max$ ) whilst aerobic capacity represents the highest fractional utilisation of $\dot{V} O 2$ max that can be sustained in prolonged exercise. A useful indicant of this capacity is the so-called 'anaerobic threshold' which is more amenable to training than is $\dot{V} O 2$ max .

The importance of $\dot{V} O_{2} \max$ was emphasised in the squad values reported for Hungarian teams by Apor (1988). There was a direct correlation between the average $\dot{V} O_{2}$ max of players and the team's finishing position in the national league. Mean values in contemporary top teams exceed $65 \mathrm{ml} . \mathrm{kg}$ ' $\mathrm{min}^{-1}$, although there is variability due to positional role (Wisloff et al., 1998). It is likely that there is a threshold value around $60 \mathrm{ml}^{\prime} \mathrm{kg}^{-1} \cdot \mathrm{min}^{-1}$, below which an individual player is unlikely to perform successfully in top-class contemporary soccer.

Youth players are still developing in body size and physiological function, and so data for the latter may need to be scaled appropriately in any interpretation of comparisons with adult values. Even so, observations for talented young elite players confirm the importance of aerobic power (Reilly et al., 2000b) for participation at an high level. Nevertheless, the need for fitness over a range of measures was emphasised when elite young players, aged 16.2- 16.6 years, were compared with an aged-matched sub-elite group 
(see Table 1). The former had the higher values for $\dot{V} O_{2}$ max but were leaner and faster also in sprinting over $5 \mathrm{~m}, 15 \mathrm{~m}$ and $30 \mathrm{~m}$. Besides, the elite players were much the superior in an agility run and in vertical jumping.

Table I. Physiological characteristics of elite and sub-elite soccer players (mean $\pm \mathrm{s}$ ). data are from Reilly et al. (2000a)

\begin{tabular}{l|c|c}
\hline & Elite & Sub-elite \\
\hline Speed & $1.04 \pm 0.03$ & $1.07 \pm 0.06$ \\
$5-m$ sprint (s) & $2.44 \pm 0.07$ & $2.56 \pm 0.12$ \\
15-m sprint (s) & $3.67 \pm 0.13$ & $3.79 \pm 0.17$ \\
$25-m$ sprint (s) & $4.31 \pm 0.14$ & $4.46 \pm 0.21$ \\
$30-m$ sprint (s) & $59.0 \pm 1.7$ & $55.5 \pm 3.8$ \\
Speed endurance & $6.42 \pm 0.16$ & $6.74 \pm 0.29$ \\
$\dot{V} O 2$ max (ml. $\left.\mathrm{kg}^{-1} \cdot \mathrm{min}^{-1}\right)$ & $0.25 \pm 0.19$ & $0.39 \pm 0.37$ \\
Mean time (s) & $6.24 \pm 0.19$ & $6.74 \pm 0.31$ \\
Fatigue index (s) & $55.80 \pm 5.82$ & $50.21 \pm 7.58$ \\
Speed endurance (s) & $7.78 \pm 0.18$ & $9.53 \pm 0.73$ \\
Power (SV), cm) & & \\
Agility performance (s) & &
\end{tabular}

Abbreviation: SVJ = standing vertical jump.

Observations on professional soccer players also underline the need for quickness over short distances to complement a good oxygen transport system. Strudwick et al. (2002) compared anthropometric and fitness profiles of elite players in soccer and in Gaelic football. The combined groups were described as lean and muscular with a reasonably high level of capability in all areas of physical performance. Intra-group variability among the soccer players was attributed to the specificity of positional roles. Whilst both groups displayed good average values for aerobic power, the soccer players were superior in anaerobic performance.

Top-class players adapt to the demands of the game and these adaptations are reflected in their fitness profiles. Players may not need to have an extraordinary capacity within any discrete area of physical performance but must possess a reasonably high level within all areas. Early profiling of youth players may help to identify particular areas of weakness or deficiency which can then be redeemed by appropriate training regimens.

To a very large extent the positional role of a player is related to the player's physiological capacities. This harmonisation is evidence of an ergonomics model being realised. For example, midfield players and full-backs tend to have the highest $\dot{V} O_{2}$ max values and perform best in intermittent exercise tests, but have the lowest muscle strength. Physiological variables are 
both influenced by genetics and amenable to training so that in my interpretation of fitness data on young players, their trainability should be considered.

\section{TRAINING}

Training sessions are part of the occupational demands on professional players, being a formal preparation for their public competitive engagements. For young players the training environment is recreational in nature but for talented players on systematised programmes their regimens form a preparation for achieving long-term career goals. Nevertheless, lessons for training of youth players may be drawn from observations on the demands of elite competition on one hand and on training responses of young players on the other.

Fatigue during competitive match-play is reflected in declining muscle glycogen stores, rising core body temperatures and hypohydration due to seating. Mental fatigue is evident in an increase in errors and faults in concentration and decision-making as the game nears its end. There is also a decrease in muscle strength, a factor which may predispose to injury. For all these reasons, it is inadvisable to allow fatigue to occur due to prolonged training sessions where youth players are concerned.

Reilly and Ball (1984) showed that training with the ball optimised the physiological training stimulus compared to running at the same pace but without the ball. Working with the ball provides the added benefit of practising soccer skills. This criterion means that specific training drills should be sought which maximise game-related activity whilst sustaining an acceptable training intensity. Consequently, small-sided games may have an advantage over I I-a-side training matches for youth players.

Platt et al. (200I) compared 3-a-side and 5-a-side matches among nonelite players aged $10-12$ years. The size of the pitch was modified to suit the number of players involved. The 3 vs 3 condition was superior to 5 vs 5 in a number of respects. There were more bouts of high-intensity activity and fewer bouts of lower intensity in the former. There was more engagement with the ball and more tackles executed (see Figure 2). Furthermore, the mean heart rate was higher in 3 vs 3 (184 beat.min ${ }^{-1}$ ) than in 5 vs 5 ( 172 beats. $\mathrm{min}^{-1}$ ), the difference being sustained throughout the 15 min of play. These values equated to $88 \%$ and $82 \%$ of players' predicted maximum heart rate. It seems therefore that the 3 vs 3 small-sided games provided not only the best opportunity for game-related activity but also the better physiological training stimulus. 


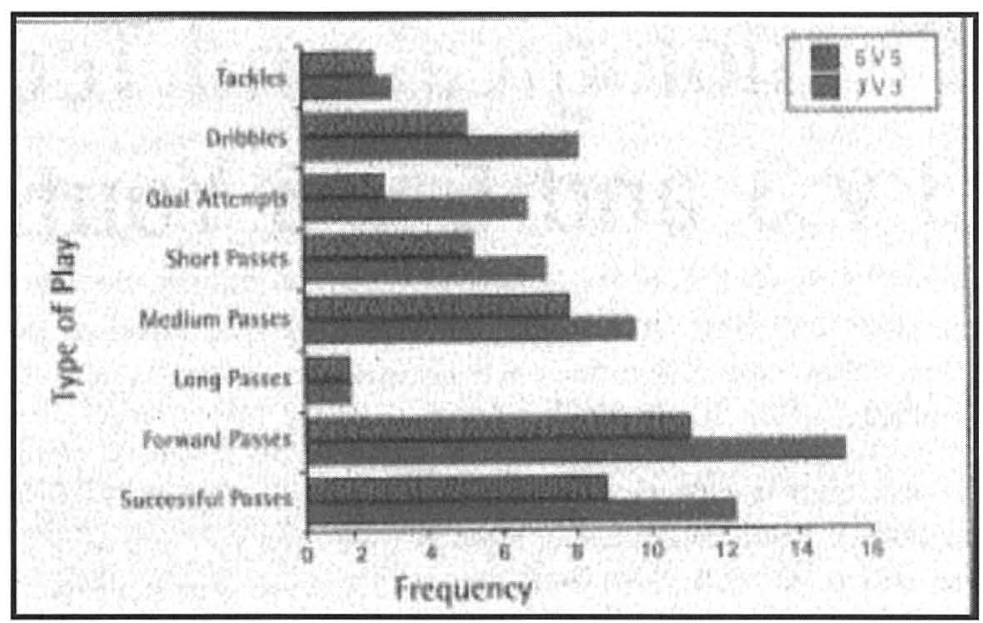

Figure 2. A comparison of player involvement during 5 vs 5 and 3 vs 3 games.

\section{CIRCULATORY RESPONSE DURING CHILDREN'S SOCCER PLAY}

Monitoring of heart rate permits a realistic assessment to be made of the circulatory strain during match-play. Drust and Reilly (1997) measured the heart rates of children aged 7-13 years playing 8-a-side matches, each for 10 min. The mean heart rates were $170 \pm 18$ beats. $\mathrm{min}^{-1}$ for the boys and $167 \pm$ 20 beats. $\mathrm{min}^{-1}$ for the girls. Five players who participated in a further 10-min game immediately afterwards displayed mean heart rates of $179 \pm 8$ beats.min ${ }^{1}$ and $|8| \pm 5$ beats. $\mathrm{min}^{-1}$ for the $1^{\text {st }}$ and $2^{\text {nd }}$ halves of this extra match. These values are comparable to the 182 beats. min $^{-1}$ in 5 vs 5 observed by Platt et al. (200I) over a 15-min match in 10 to 12-year olds.

Klimt et al. (1992) studied the physiological demands of matches in German players under II and under 12 years. Heart rates were in the range 160-180 beats. $\mathrm{min}^{-1}$, values roughly comparable with those observed in adults. Blood lactate levels stayed in the range 3-4 mmol. $\mathrm{I}^{-1}$, reflecting the completion of high-intensity efforts by children without major accumulation of lactate.

Seyers et al. (2002) considered whether late-maturing soccer players were at a physiological disadvantage compared to early maturers. They focused in particular on running economy in young players between 12 and 16 years of age. Running economy was assessed at three sub-maximal running intensities and allometric coefficients were used to take into account differences in body size. They were unable to find any physiological differences which could explain why the late maturers were able to keep up with the early maturers. Running style rather than age or maturation appeared to be the important determinant of running economy in these young soccer players. 


\section{TRAINING PRESCRIPTION FOR CHILDREN AND YOUTHS}

It is inappropriate to extrapolate from data on professional players in prescribing training for children. Professional players have been estimated to expend 14.4 MJ.day ${ }^{-1}$ on average while training (Reilly and Thomas, 1979). Such a training load would place inordinate demands on the daily energy requirements of young soccer players. Consequently, modifications are made for under-age matches and their programmes regulated accordingly. Furthermore, they are likely to pace themselves appropriately in open recreational play.

In the USA, matches at under-8 are divided into 4 quarters each of 12 min. At under- 10 each half lasts 25 min, extended to 30 min at under- 12 and $45 \mathrm{~min}$ at under-19. In tandem with these modifications are changes to the size of the pitch, the number of players and the regulations for substitutions. These rules are aimed at reducing the overall load on young players whilst allowing the game to retain its intermittent high-intensity nature.

Linquist and Bangsbo (1993) studied II 12 young Danish soccer players aged 10-17 years with a view to establishing whether they need specific physical training. The young players performed soccer-specific field tests and their results were compared with those of adult players. The authors concluded that specific physical training should have a low priority until late puberty. They considered that the time could be better devoted to other types of training such as a focus on technical aspects.

A concern about possible injuries in young Japanese soccer players led Kohno and colleagues (1997) to study participants aged 12 to 18 years. The junior high school players (between 12 and 15 years) practised for 4.5 h.week ' on average, whilst the training of the senior high school players lasted 5.4 h.week ${ }^{-1}$ on average. The authors monitored injuries, muscle strength and maximal oxygen uptake in each of the seven groups (i.e. ages 12 to 18 inclusive). They concluded that injuries could be decreased by taking changes in fitness levels of adolescent players into consideration when designing training programme for them. Their prescriptions were as follows:

- From age 12 to 13 it is best to conduct technical exercises that do not overload the knee joint;

at age 14, training may progress to improving muscle power (with appropriate loads) and sprinting;

- at age 16, endurance training may be introduced;

- $\quad$ training should be adjusted to different levels of fitness according to age. 


\section{OVERVIEW}

Observations on the physiological demands of competitive football provide insights into the physiological capabilities needed to cope with these demands. Such capabilities are multifactorial and can be enhanced by specific training. Allowance should be made for positional role and for the level of competition. Observations on young players demonstrate a capability to pace themselves appropriately for the shorter durations of matches. Young players should never be considered as miniature adults and during development a priority should be placed on skills acquisition, technical aspects and enjoyment of play. As talented players move into systematic training programmes to accelerate their development, they need to be able to tolerate high training loads. It is essential that in the process of optimising their development, the youngsters' capabilities are not overstretched.

\section{REFERENCES}

Apor P (1988). Successful formulae for fitness training. In T Reily, A Lees, K Davids, WJ Murphy (Eds). Science and Football. London: E and FN Spon. Pp. 95-107

Bangsbo J (1994). Energy demands in competitive soccer. Joumal of Sports Sciences, 12, S5-SI2.

Borms J (1986). The child and exercise: an overview. Joumal of Sports Sciences, 4, 3-20.

Drust B, Reilly $T$ (1997). Heart rate responses of children during soccer play. In $T$ Reilly, J Bangsbo, M Hughes (Eds). Science and Football III. London: E and FN Spon. Pp. 196-200.

Drust B, Reilly T, Cable NT (2000). Physiological responses to laboratory-based soccer-specific intermittent and continuous exercise. Journal of Sports Sciences, 18, 885-892.

Ekstrand J (1982). Soccer injuries and their prevention. Thesis, Linköping University, Medical Dissertation 130

Klimt F, Betz M, Seitz U (1992). Metabolism and circulation system of children playing soccer. In J Coudert, E Van Praagh (Eds). Children and Exercise XVI: Paediatric Work Physiology. Paris: Maason. Pp. 127-129.

Kohnon T, O'Hata N, Ohara M, Shirahata T, Endo Y, Satoh M, Kimura Y, Nakajima Y (1997). Sports injuries and physical fitness in adolescent soccer players. In T Reilly, J Bangsbo, M Hughes (Eds). Science and Football III. London: E and FN Spon. Pp. I85189

Lindquist F, Bangsbo J (1993). Do young soccer players need specific physical training? In T Reilly, J Clarys, A Stibbe (Eds). Science and Football II. London: E and FN Spon. Pp 275-280.

Platt D, Maxwell A, Horn R, Williams M, Reilly T (200 I). Physiological and technical analysis of $3 \vee 3$ and $5 \vee 5$ youth football matches. Insight: The F. A. Coaches Association Journal, 4 (4), 23-24.

Reilly $T$ (1997). Energetics of high intensity exercise (soccer) with particular reference to fatigue. Joumal of Sports Sciences, 15, 257-263. 
Reilly T, Ball D (1984). The net physiological cost of dribbling a soccer ball. Research Quarterly for Exercise and Sport, 55, 267-27l.

Reilly T, Stratton G (1995). Children and adolescents in sport: physiological considerations. Sports Exercise and Injury. I, 207-213.

Reilly $T$, Thomas $V$ (1979). Estimated daily energy expenditures of professional association footballers. Ergonomics, 22, 541-548.

Reilly T, Bangsbo J, Franks A (2000). Anthropometric and physiological predispositions for elite soccer. Joumal of Sports Sciences, 18, 669-683.

Reilly T, Williams AM, Nevill A, Franks A (2000). A multidisciplinary approach to talent identification in soccer. Journal of Sports Sciences, 18, 695-702.

Segers V, De Clercq D, Philippaerts R, Jonssens M (2002). Running economy in early and late mature youth soccer players. In P Aerts, K D'Aout, A Herrel, R Van Damme (Eds). Topics in Functional and Ecological Vertebrate Morphology. Maastricht: Shaker Publishing. Pp. 125-138.

Strudwick A, Reilly T, Doran D (2002). Anthropometric and fitness profiles of elite players in two football codes. Journal of Sports Medicine and Physical Fitness, 42, 239242.

Wagenmakers AJ, Brooks JH, Coakley JH, Reilly T, Edwards RHT (1989). Exerciseinduced activation of the branched chain 2-oxo acid dehydrogenase in human muscle. European Journal of Applied Physiology, 59, 159-167.

Wisloff U, Helgerud J, Hoff J (1998). Strength and endurance of elite soccer players. Medicine and Science in Sports and Exercise, 30, 462-467. 
Série

Investigacão

Coimbra

Imprensa da Universidade

2004 